\title{
Production, purification and characterization of an exo-polygalacturonase from Penicillium janthinellum sw09
}

\author{
YUPING MA ${ }^{1}$, SIWEN SUN ${ }^{2}$, HUI HAO ${ }^{1}$ and CHUNPING XU $^{2}$ \\ ${ }^{1}$ Technical Center of China Tobacco Henan Industrial Co. Ltd, Longhai road 72, Zhengzhou, Henan 450016, China \\ ${ }^{2}$ College of Food and Biology Engineering, Zhengzhou University of Light Industry, Dongfeng road 5, Zhengzhou 450002, China
}

Manuscript received on January 23, 2015; accepted for publication on March 3, 2015

\begin{abstract}
A soil isolate, Penicillium janthinellum sw09 has been found to produce significant amounts of an extracellular pectinase subsequently characterized as exo-polygalacturonase (exo-PG). By optimizing growth conditions, P. janthinellum sw09 produced high amount of exo-PG (16.54 units $/ \mathrm{mL})$. The crude enzyme was purified by gel filtration chromatography and two exo-PG activity peaks (designated as PGI and PGII) were revealed. On SDS-PAGE analysis, purified PGII using DEAE-Sepharose FF column, was found to be a single band with a molecular mass of $66.2 \mathrm{kDa}$. The purified PGII exhibited maximal activity at the temperature of $45^{\circ} \mathrm{C}$ and $\mathrm{pH}$ 5.0. The stability profiles show that PGII is more stable in the $\mathrm{pH}$ range of 4.0-8.0 and below $60{ }^{\circ} \mathrm{C}$. The $\mathrm{K}_{\mathrm{m}}$ and $\mathrm{V}_{\max }$ for the enzyme was $1.74 \mathrm{mg} / \mathrm{mL}$ and $18.08 \mu \mathrm{mol} /$ $(\mathrm{mL} \cdot \mathrm{min})$, respectively. Due to this enzymatic characterization, this pectinase is an attractive candidate for applications in degradation of pectin.
\end{abstract}

Key words: Penicillium janthinellum, polygalacturonase, purification, characterization.

\section{INTRODUCTION}

Pectinases constitute a unique group of enzymes which catalyze the degradation of pectic polymers present in the plant cell walls (Torres-Favela et al. 2003). Polygalacturonases (PGs) (EC 3.2.1.67) are part of a group of pectinases that possess hydrolytic functions and are able to cleave the $\alpha-1,4$ glycosidic bonds between the two non-esterified galacturonic acid residues in pectin and pectic substances (Mohamed et al. 2006, Niture 2008). PGs have been classified according to their substrate specificity and the position of the bonds which they hydrolyse.

Correspondence to: Chunping $\mathrm{Xu}$

E-mail: c.p.xu@zzuli.edu.cn
Endo-PG was defined as hydrolysing the a-1,4glycosidic bonds in the substrate at random, whilst exo-PG hydrolyses the terminal link (Niture 2008). These enzymes are used in different sectors, such as paper, textile, cellulose, and food industries and have many important industrial applications (Joslyn et al. 1952, Kashyap et al. 2001). Additionally, PGs can promote the clarification of wine and grape juice (Sanderson and Spotts 1995).

PG from microbial source is the most important pectinase used in industries. Although a number of organisms producing pectinases have been reported, the selection of potential isolates still remains a tedious task, especially when physiologically potential strains are obtained to achieve 
maximum yield (Pandey et al. 1999). Most of the commercial PGs produced, are investigated from Aspergillus species (Mathew et al. 2008). The purification of PG is an important tool for understanding its properties and it reveals the structure and functional mechanism which are important for knowledge regarding the action of these enzymes in the plant infections process, in industrial application, in addition to their importance in biomass degradation. Fungal PGs are generally monomeric proteins with a carbohydrate content of $5-85 \%$ and molecular masses in the range of 20 to $95 \mathrm{kDa}$ (Borin et al. 1996, Devi and Rao 1996, Mathew et al. 2008, Niture 2008, Niture and Rao 2004).

In this paper, the production medium of exo-PG obtained from $P$. janthinellum sw09 by submerged culture was optimized by orthogonal design. Furthermore, purification and physicochemical properties of exo-PG were investigated.

\section{MATERIALS AND METHODS}

\section{MICROORGANISM AND GROWTH CONDITIONS}

The microorganism used in this study was Penicillium janthinellum sw09, isolated from a tobacco field in Xuchang, P.R. China, and maintained as stock culture on potato dextrose agar (PDA) medium containing $0.3 \%$ citrus pectin at 4 ${ }^{\circ} \mathrm{C}$. This strain was identified by Sangon Biotech (Shanghai) Co., Ltd and preserved at the Henan Province Microbiological Culture Collection Center (HPMCC no. 1225853). The liquid culture of mycelia was initiated by transferring the fungal mycelia from the stock culture on a Petri dish into the seed culture medium. The seed culture was propagated in a $250 \mathrm{~mL}$ Erlenmeyer flask containing $100 \mathrm{~mL}$ of liquid medium $(10 \mathrm{~g} / \mathrm{L}$ yeast extract, 5 $\mathrm{g} / \mathrm{L}$ citrus pectin, $\mathrm{FeSO}_{4} 0.1 \mathrm{~g} / \mathrm{L}, \mathrm{MgSO}_{4} 0.5 \mathrm{~g} / \mathrm{L}$, $\mathrm{KH}_{2} \mathrm{PO}_{4} 1 \mathrm{~g} / \mathrm{L}$, and $\mathrm{pH} 6.0$ ) at $28{ }^{\circ} \mathrm{C}$ on a shaking incubator at $160 \mathrm{rpm}$ for $72 \mathrm{~h}$. The exo-PG was produced with the inoculation of $4 \%(\mathrm{v} / \mathrm{v})$ of the seed culture by submerged fermentation in a stirred tank bioreactor (Infors, Switzerland, 3.5-L working volume). The fermentations were performed under the following conditions: temperature, 32 ${ }^{\circ} \mathrm{C}$, aeration, $2 \mathrm{vvm}$; agitation speed, $160 \mathrm{rpm}$. All experiments were performed in triplicate to ensure the trends observed were reproducible.

\section{OPTIMIZATION PROCEDURE}

Orthogonal design is one of the important statistical methods that use the Taguchi method (Taguchi 1986). Taguchi method is a fast and considerable way of optimization conferring outcome in simultaneous study of many factors, making its mark in quality products supplemented with better process performance, and rendering high yield and better stability through limited experimental trials. This approach has been successfully applied to optimize medium composition, condition of enzyme reaction, and extraction conditions for bioactive compounds (De Oliveira and Alves 2000, Xu et al. 2003). An orthogonal $\mathrm{L}_{9}(3)^{4}$ test design was applied to optimize medium condition of PG by $P$. janthinellum in flask culture. As seen on Table I, the experiment was carried out with 4 factors with 3 levels based on preliminary single experimental results. The exo-PG yield was chosen as the response.

TABLE I

Experimental factors and their levels for orthogonal projects.

\begin{tabular}{ccccc}
\hline Level & $\begin{array}{c}\text { Glucose } \\
(\mathrm{g} / \mathrm{L})\end{array}$ & $\begin{array}{c}\text { Yeast } \\
\text { extract } \\
(\mathrm{g} / \mathrm{L})\end{array}$ & $\begin{array}{c}\mathrm{KH}_{2} \mathrm{PO}_{4} \\
(\mathrm{~g} / \mathrm{L})\end{array}$ & $\begin{array}{c}\text { Citrus pectin } \\
(\mathrm{g} / \mathrm{L})\end{array}$ \\
\hline 1 & 30 & 3 & 0.5 & 2 \\
2 & 40 & 4 & 1 & 4 \\
3 & 50 & 5 & 1.5 & 6 \\
\hline
\end{tabular}

ENZYME ACTIVITY MEASUREMENTS

The activity of exo-PG was assayed in a reaction mixture containing $1 \%$ citrus pectin solution with a degree of esterification (D.E.) of $67-70 \%$ (CAS 
no. 9000-69-5, Sigma) in $0.2 \mathrm{M}$ sodium acetate buffer (pH 5.0) at $45^{\circ} \mathrm{C}$ for $30 \mathrm{~min}$. The number of reducing groups, released by enzymatic action, was measured by the DNS method (Miller 1959) and expressed as galacturonic acid. One unit of enzyme activity (U) was defined as the amount of enzyme releasing one $\mu \mathrm{mol}$ of galacturonic acid per minute under the assay conditions (Martins et al. 2002).

\section{ENZYME PURIFICATION PROCEDURE}

After $72 \mathrm{~h}$ of fermentation, the culture broth was centrifuged at 9,000 $\mathrm{g}$ for $15 \mathrm{~min}$, and the resulting supernatant was filtered through a membrane filter ( $0.45 \mu \mathrm{m}$, Millipore). The resulting culture filtrate was precipitated by ammonium sulfate (20-100\%) and the mixture was stirred for $2 \mathrm{~h}$, and centrifuged at $15,000 \mathrm{~g}$ for $30 \mathrm{~min}$. The ammonium sulphate fraction was dialyzed against Tris- $\mathrm{HCl}$ buffer (50 $\mathrm{mM}, \mathrm{pH} 6.5$ ) and directly loaded on a Sepharose CL$6 \mathrm{~B}$ gel filtration column $(2.5 \times 60 \mathrm{~cm})$ equilibrated with $13 \mathrm{mM} \mathrm{Na}_{2} \mathrm{HPO}_{4}$-citric acid buffer $(\mathrm{pH}$ 5.0). Protein fractions collected from the column, corresponding to the protein peak, were pooled and further applied to the DEAE-Sepharose FF based anion exchangers column equilibrated with $20 \mathrm{mM}$ $\mathrm{Na}_{2} \mathrm{HPO}_{4}$-citric acid buffer ( $\mathrm{pH}$ 6.5) (Mohamed et al. 2006). Fractions of $4 \mathrm{~mL}$ were collected and assayed for exo-PG activity. The objective of this procedure was to estimate the number of isoform of exo-PG presented in the crude enzyme solution. The protein fraction with exo-PG activity was desalted overnight by dialysis at $4^{\circ} \mathrm{C}$.

\section{ANALYTICAL ELECTROPHORESIS}

The molecular weight of the purified enzyme was determined by SDS-PAGE in a Mini Protean II apparatus $(10 \times 8 \mathrm{~cm})$ (Biorad). Electrophoresis was carried out in a vertical slab gel apparatus (Beijing Liuyi Instrument Factory, DYCZ-24DN) with a 5\% $(\mathrm{w} / \mathrm{v})$ polyacrylamide stacking gel and $12 \%(\mathrm{w} / \mathrm{v})$ resolving gel in Tris/glycine buffer $(\mathrm{pH} 8.3)$ with the Sigma molecular weight marker MP102 (14.4
kDa-94.0 kDa) in a parallel lane (Laemmli 1970). The protein band was visualized by silver staining. The molecular mass of the isolated subunit was estimated by Ferguson plot analysis (Hedrick and Smith 1968).

\section{PROTEIN ESTIMATION}

Protein concentration was determined in the concentration ranges of $1-10$ and $10-100 \mu \mathrm{g} / \mathrm{mL}$ by the Bradford microassay, with bovine serum albumin (BSA) as the standard (Bradford 1976).

\section{PROPERTIES OF PURIFIED ENZYME}

All enzyme catalytic properties were assayed with $1 \%$ citrus pectin (D.E $67-70 \%$ ) as substrate using the procedure for enzyme activity determination described above and carried out with three replicates. Exo-PG activity was assayed as a function of $\mathrm{pH}$, in $\mathrm{Na}_{2} \mathrm{HPO}_{4}$-citric acid buffer $(\mathrm{pH}$ 3.0-8.0), at $45^{\circ} \mathrm{C}$, and temperature, in $\mathrm{Na}_{2} \mathrm{HPO}_{4}-$ citric acid buffer at the $\mathrm{pH}$ optimum, incubated at different temperatures between $35^{\circ} \mathrm{C}$ and $60^{\circ} \mathrm{C}$.

The thermal stability was investigated by remeasuring the activity of the purified enzyme solution after it had been kept for $2 \mathrm{~h}$, in the absence of substrate, at different temperatures in the range of $30-60{ }^{\circ} \mathrm{C}$. In these tests, the initial and final exo$\mathrm{PG}$ activities were determined at optimum $\mathrm{pH}$ and temperature. The $\mathrm{pH}$ stability of the purified enzyme was evaluated by dispersing $(1: 1, \mathrm{v} / \mathrm{v})$ enzyme solution in $\mathrm{Na}_{2} \mathrm{HPO}_{4}$-citric acid buffer ( $\mathrm{pH} 3.0-8.0$ ) and maintaining these solutions at $45^{\circ} \mathrm{C}$ for $4 \mathrm{~h}$. An aliquot was taken to determine the remaining activity at the optimum $\mathrm{pH}$ and temperature.

The Michaelis constant $\left(\mathrm{K}_{\mathrm{m}}\right)$ and $\mathrm{V}_{\max }$ values were determined from Lineweaver-Burk plots of enzyme activity measured with $67-70 \%$ D.E. citrus pectin (Sigma) as substrate, at concentrations between 2.0 and $40.0 \mathrm{mg} / \mathrm{mL}$ at optimum $\mathrm{pH}$ and temperature. The purified enzyme concentration was $0.01 \mu \mathrm{mol} / \mathrm{mL}$. The results were plotted with Excel. 


\section{STATISTICAL ANALYSES}

Unless otherwise stated, data were expressed as mean $\pm \mathrm{SD}$, and analyzed statistically by ANOVA method. P-values below 0.05 and 0.01 were regarded as statistically significant and highly significant, respectively.

\section{RESULTS AND DISCUSSION}

\section{PRODUCTION OF EXO-PG IN FLASK CULTURE}

Enzyme production is generally influenced by the composition of the medium, in particular the carbon and nitrogen sources (Gomes et al. 2009). The orthogonal matrix method was employed to optimize the concentration of the medium. The experimental conditions for each project were listed in Table II, and experimental results were also included in the last column of this table. According to the magnitude order of the $\mathrm{R}$ value (maximum difference) as shown in Table II, the order of effects of all factors on polygalacturonase production was glucose $>$ citrus pectin $>\mathrm{KH}_{2} \mathrm{PO}_{4}$ $>$ yeast extract. This result indicated that the effect of glucose was more important than that of other nutrients. In terms of the maximum $\mathrm{K}$ value of each factor based on statistical calculations, optimal composition for polygalacturonase production were $50 \mathrm{~g} / \mathrm{L}$ glucose, $3 \mathrm{~g} / \mathrm{L}$ yeast extract, $1 \mathrm{~g} / \mathrm{L}$ $\mathrm{KH}_{2} \mathrm{PO}_{4}$, and $2 \mathrm{~g} / \mathrm{L}$ citrus pectin. The significance of each factor was evaluated by calculating the $\mathrm{F}$ value and the results were summarized in Table III. Both factors, including glucose and citrus pectin had significant effects on the polygalacturonase production $(\mathrm{P}<0.01)$. In order to confirm the optimization results, the suggested medium components were confirmed in triplicate. The 16.54 $\mathrm{U} / \mathrm{mL}$ exo-PG was maximally obtained under the optimum conditions just described. This implied that the selected conditions were really the most suitable. Mathew et al. (2008) found the optimal pectin level as being $1.0 \mathrm{~g} / \mathrm{L}$ for exo-PG production by a Penicillium strain in submerged culture, which suggests that the level of substance requirement for exo-PG production depends on the nature of the specific strain, even though they belong to the same species (i.e. Penicillium).

TABLE II

Application of $\mathrm{L}_{9}\left(3^{4}\right)$ orthogonal projects to exo-PG production by $P$. janthinellum after 72 hours of incubation in flask culture.

\begin{tabular}{cccccc}
\hline Run & Glucose & Yeast extract & $\mathrm{KH}_{2} \mathrm{PO}_{4}$ & Citrus pectin & Enzymatic activity $(\mathrm{U} / \mathrm{mL})$ \\
\hline 1 & 1 & 1 & 1 & 1 & $9.51 \pm 1.07$ \\
2 & 1 & 2 & 2 & 2 & $9.69 \pm 0.27$ \\
3 & 1 & 3 & 3 & 3 & $8.18 \pm 0.22$ \\
4 & 2 & 1 & 2 & 3 & $11.56 \pm 0.01$ \\
5 & 2 & 2 & 3 & 1 & $12.16 \pm 0.43$ \\
6 & 2 & 3 & 1 & 2 & $11.10 \pm 0.82$ \\
7 & 3 & 1 & 3 & 2 & $15.96 \pm 0.20$ \\
8 & 3 & 2 & 1 & 3 & $14.74 \pm 0.08$ \\
9 & 3 & 3 & 2 & 1 & $16.27 \pm 0.15$ \\
$\mathrm{k} 1$ & 9.12 & 12.34 & 11.78 & 12.65 & \\
$\mathrm{k} 2$ & 11.61 & 12.19 & 12.51 & 12.25 & \\
$\mathrm{k} 3$ & 15.66 & 11.85 & 12.10 & 11.49 & \\
$\mathrm{R}$ & 6.53 & 0.49 & 0.72 & 1.16 & \\
Optimal level & 3 & 1 & 2 & 1 & \\
Order & glucose $>$ citrus pectin $>\mathrm{KH}_{2} \mathrm{PO}_{4}>$ yeast extract & \\
\hline
\end{tabular}


TABLE III

Variance analysis of $\mathrm{L}_{9}\left(3^{4}\right)$ orthogonal experiment on the optimization of exo-PG production.

\begin{tabular}{lccccc}
\hline Variance source & Sum of squares & Degree of freedom & Mean square & F-ratio & Significance \\
\hline A:glucose & 201.50 & 2 & 100.75 & 267.85 & $\mathrm{p}<0.01$ \\
B:yeast extract & 1.16 & 2 & 0.58 & 1.54 & \\
$\mathrm{C}: \mathrm{KH}_{2} \mathrm{PO}_{4}$ & 1.89 & 2 & 0.94 & 2.51 & $\mathrm{p}<0.01$ \\
D:Citrus pectin & 5.02 & 2 & 2.51 & 6.67 & \\
Errors & 6.77 & 18 & 0.38 & & \\
Sum & 216.32 & 26 & & & \\
\hline
\end{tabular}

\section{PURIFICATION OF EXO-PG}

The crude enzyme solution separated on a Sepharose CL-6B column, afforded two peaks of exo-PG activity (designated as PGI and PGII) suggesting two isoforms (Fig. 1a). Because the PGII had higher amount and was stronger activity than PGI, PGII was selected for further purification. When the PGII solution (tube no. 38 to 64 as shown in Fig. 1a) was combined, concentrated and loaded on a DEAE-Sepharose FF column, one peak was eluted (Fig. 1b). The results were in agreement with the reports of Mohamed et al. (2006), who observed two polygalacturonases PGI and PGII separated from Trichoderma harzianum by two chromatography steps using DEAE-Sepharose and Sephacryl S-200.

\section{CHARACTERIZATION OF EXO-PG}

The homogeneity of the purified PGII was demonstrated by the presence of one single protein band on polyacrylamide gel and its molar mass was estimated to be $66.2 \mathrm{kDa}$ as a single subunit (Fig. 2). This observation was in the range reported for PGs from several fungi, which have molecular masses ranging from 20 to $95 \mathrm{kDa}$ (Gomes et al. 2009, Silva et al. 2007). In comparison with other Penicillium sp., lower molecular weights (24.1 $\mathrm{kDa}$ ) were detected for $\mathrm{PG}$ from $P$. viridicatum (Mohamed et al. 2003).

The effect of $\mathrm{pH}$ on the $P$. janthinellum PGII activity toward polygalacturonic acid was examined at $45{ }^{\circ} \mathrm{C}$. As shown in Figure $3 \mathrm{a}$, the
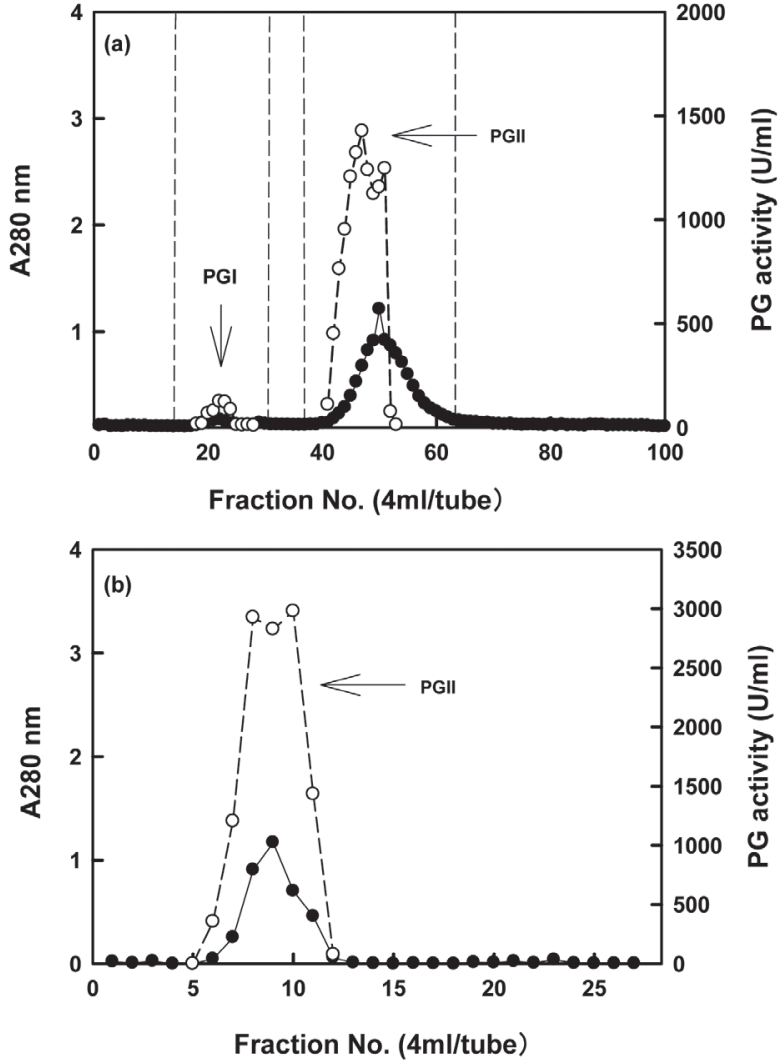

Figure 1 - Elution of exo-PG from Sepharose CL-6B gel filtration column previously equilibrated with $13 \mathrm{mM}$ $\mathrm{Na}_{2} \mathrm{HPO}_{4}$-citric acid buffer ( $\mathrm{pH}$ 5.0) (a) and DEAE-Sepharose FF column based anion exchangers column equilibrated with $20 \mathrm{mM} \mathrm{Na} \mathrm{HPO}_{4}$-citric acid buffer $(\mathrm{pH} 6.5)(\mathbf{b})$. Protein $(\bullet)$; exo-PG activity (O).

enzyme showed hydrolase activity from $\mathrm{pH} 3.0$ to 8.0, and maximum enzymatic activity $(15.72 \mathrm{U} /$ $\mathrm{mL}$ ) at $\mathrm{pH}$ 5.0. The same $\mathrm{pH}$ optimum was reported for PGs from Asergillus niger (Behere et al. 1993), T. harzianum (Mohamed et al. 2006). The effect of $\mathrm{pH}$ on the stability of $P$. janthinellum PGII was 


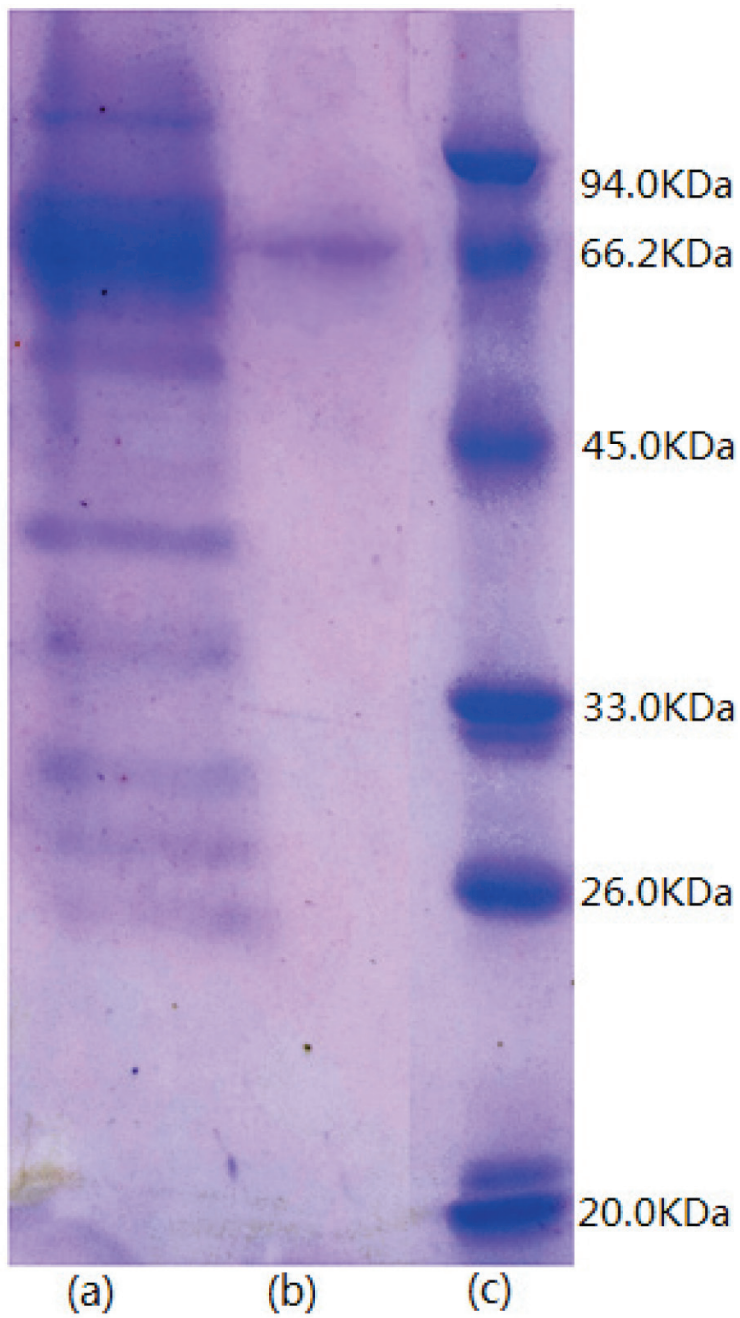

Figure 2 - SDS-PAGE of exo-PG (a), purified PGII (b) and standard proteins (c) from DEAE-Sepharose FF chromatography.

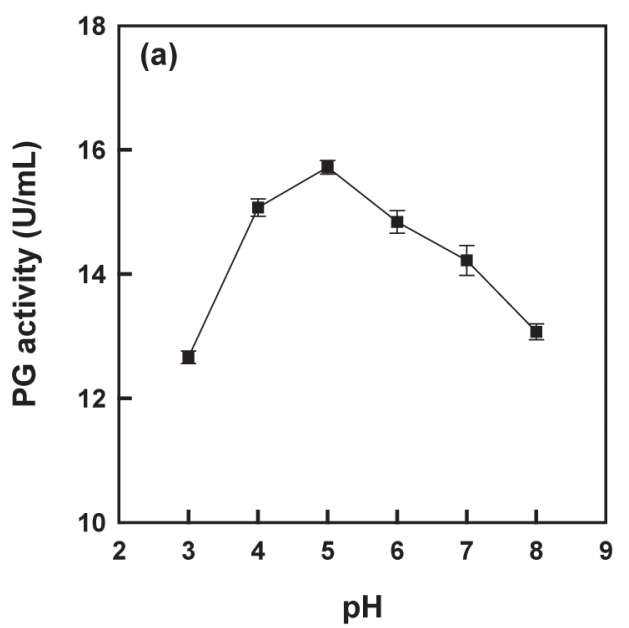

investigated by incubating the enzyme at $45^{\circ} \mathrm{C}$ at different $\mathrm{pH}$ 's for $4 \mathrm{~h}$. The results showed that the enzyme was the most stable in $\mathrm{pH}$ of 6.0 , with $90-100 \%$ of the full activity in a broader $\mathrm{pH}$ range of 4.0-8.0 (Fig. 3b). This is in agreement with the results reported by Kobayashi et al. (2001) for Bacillus sp. PG. They reported that PG activity was very stable in various $50 \mathrm{mM}$ buffers between $\mathrm{pH} 6$ and 12 when incubated at $30{ }^{\circ} \mathrm{C}$ for $1 \mathrm{~h}$.

With regard to temperature, optimal $P$. janthinellum exo-PG activity was observed at $45^{\circ} \mathrm{C}$ (Fig. 4a). Similarly, temperature optima for PGs from $T$. reesei (Mohamed et al. 2003), Mucor flaves (Grade et al. 2003), Bacillus sp. (Kobayashi et al. 2001) and T. harzianum (Mohamed et al. 2006) were around 40 and $50{ }^{\circ} \mathrm{C}$. The effect of temperature on thermal stability of $P$. janthinellum PGII was investigated by incubation the enzyme for $2 \mathrm{~h}$ in $13 \mathrm{mM} \mathrm{Na}_{2} \mathrm{HPO}_{4}-$ citric acid buffer, $\mathrm{pH} 5.0$ at different temperature ranging from 30 to $60{ }^{\circ} \mathrm{C}$ prior to substrate addition (Fig. 4b). In the absence of substrate for 1 h, PGII showed $83-100 \%$ of the original activity at $30-60$ ${ }^{\circ} \mathrm{C}$. After $2 \mathrm{~h}$, PGII showed $68-88 \%$ of the original activity at $30-50{ }^{\circ} \mathrm{C}$, while at $60^{\circ} \mathrm{C}$, the enzyme lost $58 \%$ of its initial activity. Similarly, Kobayashi et al. (2001) found that Bacillus sp. PG was stable up to $50-55^{\circ} \mathrm{C}$ in the presence of $\mathrm{CaCl}_{2}$.

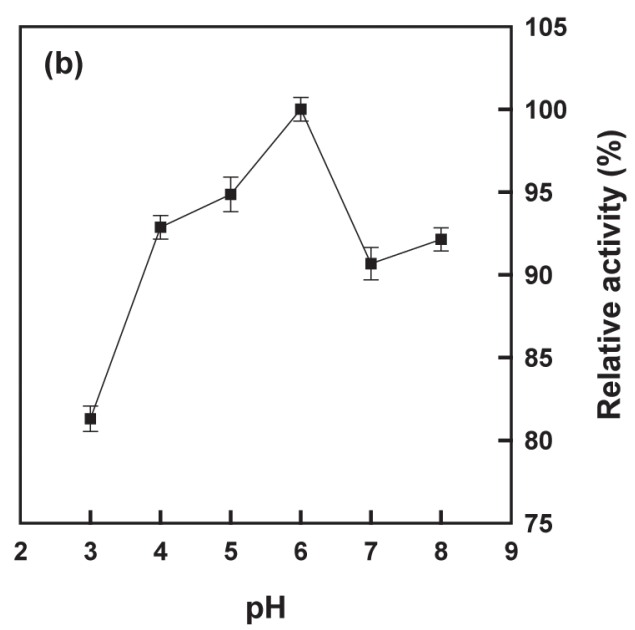

Figure 3 - Effect of pH on PGII activity (a) and PGII stability (b). 

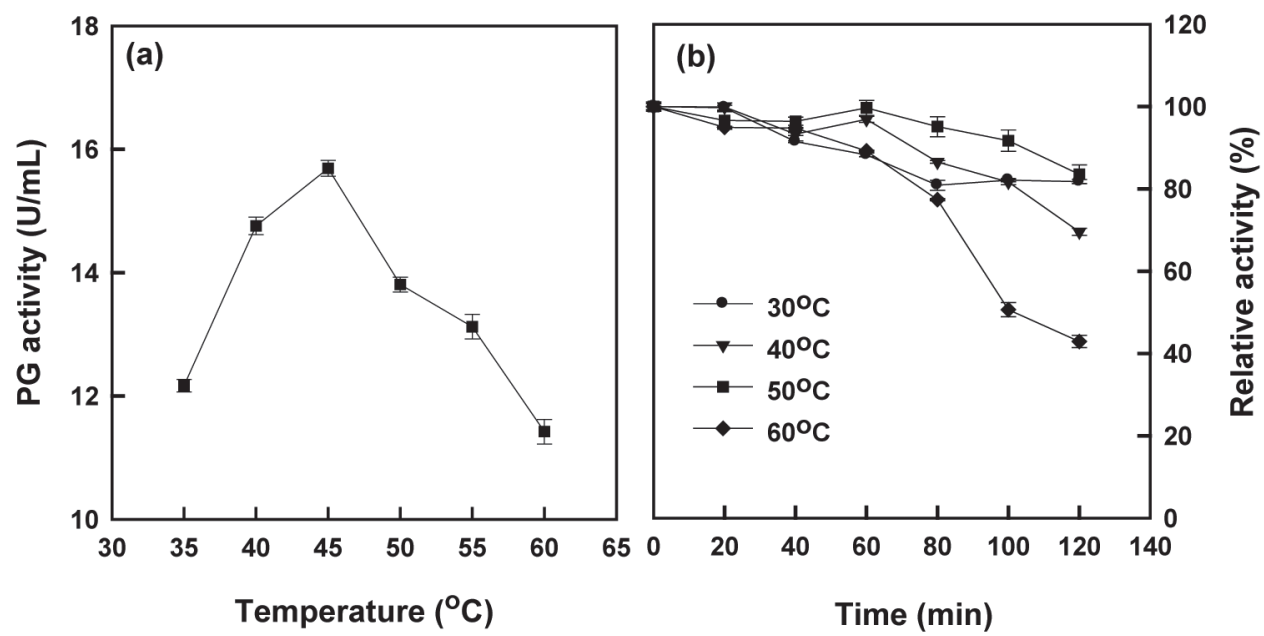

Figure 4 - Effect of temperature on PGII activity (a) and PGII stability (b).

The kinetic parameters of $P$. janthinellum PGII affinity for citrus pectin and different pectins at $\mathrm{pH} 5.0$ and $45{ }^{\circ} \mathrm{C}$ were determined by a typical double reciprocal Lineweaver-Burk plot (Fig. 5). The $\mathrm{K}_{\mathrm{m}}$ and $\mathrm{V}_{\max }$ for the enzyme was $1.74 \mathrm{mg} / \mathrm{mL}$ and $18.08 \mu \mathrm{mol} /(\mathrm{mL} \cdot \mathrm{min})$, respectively. The $\mathrm{K}_{\mathrm{m}}$ values of $P$. janthinellum PGII were lower than $\mathrm{K}_{\mathrm{m}} \mathrm{s}$ ranged from 2.5 to $14.08 \mathrm{mg} / \mathrm{mL}$ of PGs from $A$. niger (Parenicova et al. 1998), Neurospora crassa (Polizeli et al. 1991), T. harzianum (Mohamed et al. 2006) and Saccharomyces cerevisiae (Blanco et al. 1997). Low $\mathrm{K}_{\mathrm{m}}$ indicated that $P$. janthinellum PGII had high affinity using citrus pectin as substrate. $\mathrm{V}_{\max }$ of $P$. janthinellum PGII was in the range of $\mathrm{V}_{\max }$ s, i.e. 13.0 to $2600 \mu \mathrm{mol} /(\mathrm{mL} \cdot \mathrm{min})$ from above organisms. The Kcat for the enzyme was calculated as $301.33 / \mathrm{s}$. The $\mathrm{K}_{\text {cat }}$ values of $P$. janthinellum PGII were in the range of $\mathrm{K}_{\mathrm{cat}}$ s, i.e. 21.0 to $592 / \mathrm{s}$ from above organisms.

\section{CONCLUSIONS}

The fungal strain Penicillium janthinellum sw09 produced an exo-polygalacturonase able to release galacturonic acid as a hydrolysis product from natural D.E. pectin. This enzyme exhibited the $\mathrm{pH}$ and temperature profiles for optimum activity and stability that differed from other fungal PGs, which

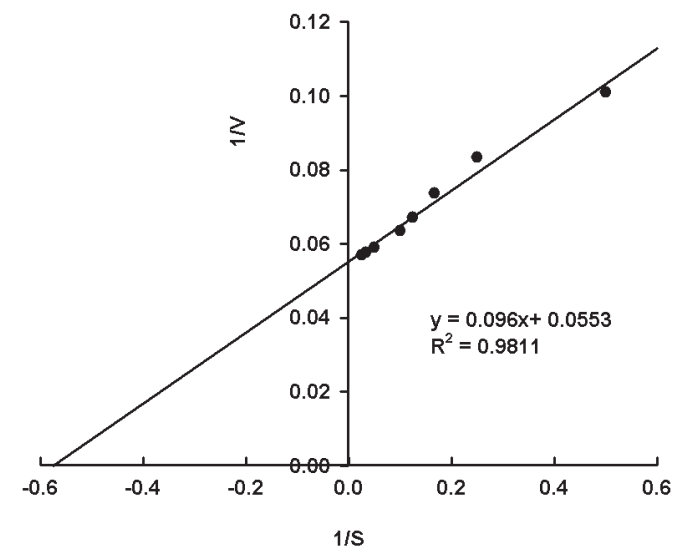

Figure 5 - Kinetics parameters of purified PGII.

kept the stability of the enzyme in a $\mathrm{pH}$ range of 4.0-8.0 and at a temperature range of $30-60{ }^{\circ} \mathrm{C}$. A thermostable nature with a high $\mathrm{pH}$ range for activity makes it possible to have wide range of industrial applications. Further works on scaleup fermentation optimization (i.e. aeration rate and agitation speed) in bioreactor and industrial application are in progress in our laboratory.

\section{RESUMO}

Penicillium janthinellum sw09, isolado do solo, produz quantidades significativas de uma pectinase extracelular que foi posteriormente caracterizada como exo-poligalacturonase (exo-PG). Ao otimizar as condições de crescimento, $P$. janthinellum sw09 produz quantidades 
elevadas de exo-PG (16,54 unidades/ml). A enzima impura foi purificada por cromatografia de filtração em gel e dois picos com atividade elevada de exo-PG (designados como PGI e PGII) foram revelados. Por análise em SDS-PAGE, PGII foi purificada utilizando uma coluna de DEAE-Sepharose FF, observou ser formada por uma única banda com uma massa molecular de 66,2 kDa. PGII purificada exibiu uma actividade máxima a uma temperatura de $45^{\circ} \mathrm{C}$ e pH 5,0. Os perfis de estabilidade mostram que PGII é mais estável numa faixa de $\mathrm{pH}$ de 4,0-8,0 e abaixo de $60^{\circ} \mathrm{C}$. O Km e Vmax para a enzima foi de $1,74 \mathrm{mg} / \mathrm{ml}$ e $18,08 \mu \mathrm{mol} /(\mathrm{mL} \cdot \min )$, respectivamente. Devido a esta caracterização enzimática, pectinase é um candidato atrativo para ser aplicado na degradação da pectina.

Palavras-chave: Penicillium janthinellum, poligalacturonase, purificação, caracterização.

\section{REFERENCES}

BEHERE A, SATYANARAYAN V AND PADWAL-DESAI SR. 1993. Separation and limited characterization of three polygalacturonases of Aspergillus niger. Enzyme Microb Tech 15: 158-161.

Blanco P, SieIRO C, REBOREdO NM AND VILla TG. 1997. Genetic determination of polygalacturonase production in wild-type and laboratory strains of Saccharomyces cerevisiae. Arch Microbiol 167: 284-288.

BORIN MDF, SAID S AND FONSECA MJV. 1996. Purification and biochemical characterization of an extracellular endopolygalacturonase from Penicillium frequentons. J Agr Food Chem 44: 1616-1620.

BRADFORD MM. 1976. A rapid and sensitive method for the quantitation of microgram quantities of protein utilizing the principle of protein-dye binding. Anal Biochem 72: 248-254.

De OliveirA D AND Alves TLM. 2000. A kinetic study of lipase-catalyzed alcoholysis of palm kernel oil. Appl Biochem Biotech 84-86: 59-68.

DEVI NA AND RAO AGA. 1996. Fractionation, purification, and preliminary characterization of polygalacturonases produced by Aspergillus carbonarius. Enzyme Microbiol Tech 18: 59-65.

Gomes E, LeIte RSR, DA SILVA R AND SILVA D. 2009. Purification of an Exopolygalacturonase from Penicillium viridicatum RFC3 Produced in Submerged Fermentation. Int J Microbiol 2009: 8.

GRADE RV, VAN DRIESSCHE G, VAN BEEUMEN J AND BHAT MK. 2003. Purification, characterization and mode of action of an endopolygalacturonase from the psychrophilic fungus Mucor flavus. Enzyme Microbiol Technol 32: 321330.
HEDRICK JL AND SMITH AJ. 1968. Determination of the molecular weight of proteins by electrophoresis in slab gels with a transverse pore gradient of crosslinked polyacrylamide in the absence of denaturing agents. Arch Biochem Biophys 126: 155-164.

JOSLYN NA, MIST S AND LAMBART E. 1952. Clarification of apple juice by fungal PG preparations. Food Technol 6: 133-139.

KASHYAP DR, VOHRA PK, CHOPRA S AND TEWARI R. 2001. Applications of pectinases in the commercial sector: a review. Bioresource Technol 77: 215-227.

KoBAYASHi T, Higaki N, SUZUMATSU A, SAWAdA K, Hagihara H AND Kawai S. 2001. Purification and properties of a highmolecular-weight, alkaline exopolygalacturonase from strain of Bacillus. Enzyme Microbiol Technol 29: 70-75.

LAEMMLI U. 1970. Cleavage of structural proteins during the assembly of the head of bacteriophage T4. Nature 227: 680-685.

MARTINS ES, SILVA D, DA SILVA R AND GOMES E. 2002. Solid state production of thermostable pectinases from thermophilic Thermoascus aurantiacus. Process Biochem 37: 949-954.

MATHEW A, ELDO AN AND MOLLY AG. 2008. Optimization of culture conditions for the production of thermostable polygalacturonase by Penicillium SPC-F 20. J Ind Microbiol Biotechnol 35: 1001-1005.

MILLER GL. 1959. Use of dinitrosalicylic acid reagent for determination of reducing sugar. Anal Chem 31: 426-428.

Mohamed SA, CHRistensen TMIE AND MiKKelsen JD. 2003. New polygalacturonases from Trichoderma reesei: characterization and their specificities to partially methylated and acetylated pectins. Carbohydr Res 338: 515-524.

MOHAMED SA, FARID NM, HOSSINY EN AND BASSUINY RI. 2006. Biochemical characterization of an extracellular polygalacturonase from Trichoderma harzianum. J Biotechnol 127: 54-64.

NITURE SK. 2008. Comparative biochemical and structural characterization of fungal polygalacturonases. Biologia 63: 1-19.

NITURE SK AND RAO A. 2004. Purification and biochemical characterization of polygalacturonase II produced in semi-solid medium by a strain of Fusarium moniliforme. Microbiological Res 159: 305-314.

Pandey A, SElvakumar P, Carlos RS AND PoOnam N. 1999. Solid state fermentation for the production of industrial enzymes. Curr Sci 77: 149-1620.

PARENiCOVA L, BENEN JAE, KESTER HCM AND VISSER J. 1998. pgaE encodes a fourth member of the endopolygalacturonase gene family from Aspergillus niger. Eur J Biochem 251: 72-80.

POLIZELI MT, JORGE JA AND TERENZI HF. 1991. Pectinase production by Neurospora crassa: purification and 
biochemical characterization of extracellular polygalacturonase activity. J Gen Microbiol 137: 1815-1823.

SANDERSON PG AND SPOTTS RA. 1995. Postharvest decay of winter pear and apple fruit caused by species of Penicillium. Phytopathol 85: 103-110.

Silva D, MARTINS ES, LEITE RSR, DA SILVA R, FERREIRA V AND GOMES E. 2007. Purification and characterization of an exo-polygalacturonase produced by Penicillium viridicatum RFC3 in solid-state fermentation. Process Biochem 42: 1237-1243.
TAGUCHI G. 1986. Introduction to Quality Engineering, UNIPUB/Kraus International, White Plains, NY, USA, vol. $1 \& 2$.

TORRES-FAVEla E, AgUilar C, ESQUiVEl-CONTRERAS CJ And Gustavo GV. 2003. Pectinase. In Enzyme Technology. Asiatech Publisher Inc. Delhi, p. 273-296.

XU CP, KIM SW, HWANG HJ, CHOI JW AND YUN JW. 2003. Optimization of submerged culture conditions for mycelial growth and exo-biopolymer production by Paecilomyces tenuipes C240. Process Biochem 38: 1025-1030. 
